\title{
Phase to phase fault detection of 3-phase induction motor using FRA technique
}

\author{
A. A. Alawady ${ }^{1}$, M. F. M. Yousof ${ }^{2}$, N. Azis ${ }^{3}$, M. A. Talib ${ }^{4}$ \\ ${ }^{1,2}$ Faculty of Electrical and Electronic Engineering, Universiti Tun Hussein Onn Malaysia, Malaysia \\ ${ }^{1}$ College of Technical Engineering, The Islamic University, Najaf, Iraq \\ ${ }^{3}$ Faculty of Engineering, Universiti Putra Malaysia, Malaysia \\ ${ }^{4}$ Tenaga Nasional Berhad Research, Kawasan Institusi Penyelidikan, Malaysia
}

\section{Article Info \\ Article history: \\ Received Dec 27, 2019 \\ Revised Feb 12, 2020 \\ Accepted Mar 5, 2020}

Keywords:

Frequency response analysis Induction motor NCEPRI algorithm Phase to phase fault Stator winding fault

\section{Corresponding Author:}

A. A. Alawady,

Department of Electrical and Electronic Engineering,

Universiti Tun Hussein Onn Malaysia (UTHM),

86400, Parit Raja, Batu Pahat, Johor, Malatsia.

Email: ahmed.a.alawady@gmail.com

\begin{abstract}
The purpose for preparing this paper is to innovate a new method to detection and diagnosis the three-phase induction motor electrical failures, especially the failures that occur in Stator winding. Stator winding breakdown largely contributes to induction motor failures. To understand internal fault in induction motors winding, four cases studies of different three-phase induction motors (TPIM) were analysed according to two conditions: normal winding condition and windings shorted between two phases. In this paper, the measurement of frequency response analysis (FRA) on the stator winding with inter-phase short is presented. Additionally, Frequency Response Analysis (FRA) interpretation technique classify and quantify the fault is also proposed. For interpretation of the FRA, a statistical indicator, which is NCEPRI algorithm is used for comparison the measured responses.
\end{abstract}

This is an open access article under the CC BY-SA license.

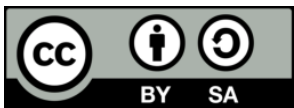

\section{INTRODUCTION}

Health of any induction motor is critical in view of availability asset management and cost. Every machine has its own estimated life. This estimate is made by considering various factors such as material used, operating condition, environmental conditions etc. Induction motors failure mechanism are different depend on different part, the most important part is stator winding [1].

According to study that presented by Electric Power Research Institute (EPRI), show that (36\%) of motor failure is because of stator winding faults $[2,3]$. Motor stator windings failure or breakdown is the most common reasons of TPIM failure [4]. Cases of induction motor failure amount reported because of this category ranged nearly from $30 \%$ to $40 \%$ [5].

Several reasons result to armature or stator windings insulation failure, among these are [6]: (a) Short circuit or starting stresses, (b) Loose bracing for end winding, (c) High stator winding temperatures, (d) Leakage in cooling systems, (e) Electrical discharges. From other side, insulation failure always related TPIM windings failure and it is countting the main reason of winding failure [5]. As evidenced by credible survey [7-10], stator winding breakdown is a large group of induction motor failures which undetected fault is considered as the root cause for this category of the faults. Any failure in windings should be detected and diagnosis in incipient level to avoid any catastrophic failure it may cause unwanted downtime of production. 
To understand the effect of short-circuit fault between winding phases in three-phase induction motor (TPIM), this paper used a new method which is frequency response analysis (FRA) technique. This is achieved by analysing four induction motors with each has a different power rating and two different conditions: (normal winding conditions and short-circuit between phases. The frequency responses (FR) of normal and faulty windings will be analysed by using the North China Electric Power Research Institute (NCEPRI) algorithm. The importance of this study is mainly to valuate the ability of FRA to detect the faulty winding in TPIM.

\section{LITERATURE OR BIBLIOGRAPHY SURVEY}

Short circuit (SC) winding faults might develop to more complicated types of stator winding faults [11]. Typically, SC stator windings occur: (a) between internal turns in same phase (turn-to-turn), (b) between two coils in same phase (coil-to-coil), (c) between two turns in diffrent phases, (d) between phase to neutral point, (e) between phase to ground and (f) open citcuit coil [12]. Figure 1 show the common faults in induction motors.

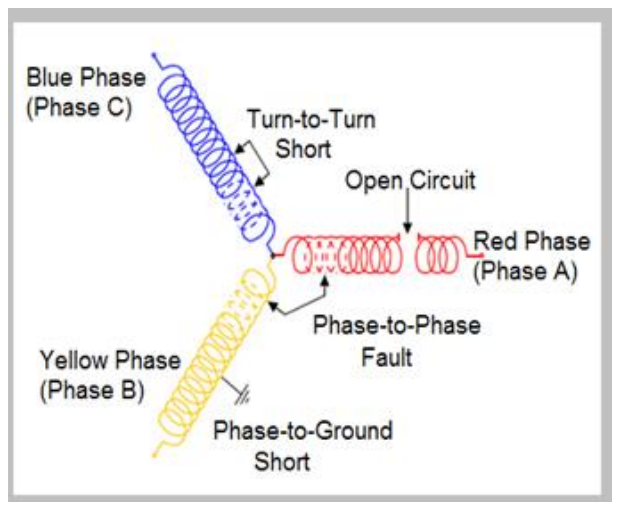

Figure 1. Induction motors common faults and Failures [12].

The types of winding faults that was clarified in the previous paragraph is named by a "stator turn faults" [13]. The responsible for stator windings failures is the stresses, which are may be classified into electrical, thermal, mechanical, and environment. The factor that most influences on for the deterioration of the insulation in most of the cases among them is the thermal stress [14]. A short-circuit (SC) turns fault causes a flow of large circulating current. Thus, this current generates excessive thermal stress in the point of shorted windings thus, that may cause for machin failure [15].

In [16], Statistical process control technique (SPCT) was used to diagnosis and detect windings faults for TPIM. A new model was estimated to detect short-circuit (SC) windings faults in time domain. An author in article [17] developed a fuzzy fault detector (FFD) by using Concordia patterns to diagnosis open-circuit (OC) faults and stator unbalance. Article [18], Discussed the performance of the TPIM and its vulnerability by modelling for detection of induction motor winding fault and its location.

References [19] and [20] reported that they used advanced signal-processing techniques (ASPT) and stator-windings-currents for stator winding fault detection of the IM. The authors in [21] analysed the deviation in frequency response (FR) by using artificial-neural-network (ANN) for faults detection. The electrical fault for induction motors field-windings was detection for first approach through FRA technique with static excitation was reported in [22].

Frequency Response Analysis FRA is an electrical non-intrusive and powerful used technique to diagnosis of many changes, faults, or abnormal conditions in the transformer winding [23]. FRA response is off-line technique for failure diagnosis and faults detection [24]. FRA is considered as one of the comparative tests which are required a reference data (RD) (at healthy operation condition) to compare with it. Therefore, the differences between RD and the new measured responses refer to there fault $[25,26]$. Each fault have finger-print or characteristic frequency response. By observation of different responses of data measured, multiple types of fault are detected and also fault severity is identified [27]. The FRA response tool can get hold of the voltage transfer function for windings frequency between (20 Hz to $2 \mathrm{MHz})[28,29]$. The important measurements connections between the FRA instrument device and other equipment such as 
transformer are four faults cases which are end-to-end short circuit connection, inter-winding inductive connection, inter-winding capacitive connection and open circuit connection [26].

\section{METHODOLOGY FOR FAULT AND MEASUREMENT}

\subsection{Experimental units choose}

Four units of three-phase induction motors were chosen to conduct this study, these units have a different rating power which are 1, 2, 3 and 5.5 horse power respectively. The specifications for these tested units are shown in Table 1. This paper focus on the Wye (Y) connection configuration between phases U, V and $\mathrm{W}$ which is widely used for TPIM. Therfore, phases for all experimental units of TPIM windings are connected as Wye (Y) winding configuration.

Table 1. Specifications of three phase induction motor units

\begin{tabular}{lcccc}
\hline \multicolumn{1}{c}{ Motor } & Motor 1 Specifications & Motor 2 Specification & Motor 3 Specifications & Motor 4 Specification \\
\hline Manufacturer & JILANG & JILANG & JILANG & JILANG \\
Model & 110RK-3DS & Y90S-2 & Y90L-2 & Y112M-2 \\
Phases & 3-Ph induction motor & 3-Ph induction motor & 3-Ph induction motor & 3-Ph induction motor \\
Power & $0.75 \mathrm{KW} / 1 \mathrm{HP}$ & $1.5 \mathrm{KW} / 2 \mathrm{HP}$ & $2.2 \mathrm{KW} / 3 \mathrm{HP}$ & $4 \mathrm{KW} / 5.5 \mathrm{HP}$ \\
Rated Voltage & $415 \mathrm{~V} / 50 \mathrm{~Hz}$ & $415 \mathrm{~V} / 50 \mathrm{~Hz}$ & $415 \mathrm{~V} / 50 \mathrm{~Hz}$ & $415 \mathrm{~V} / 50 \mathrm{~Hz}$ \\
RPM & $1500 \mathrm{rpm}$ & $2840 \mathrm{rpm}$ & $2840 \mathrm{rpm}$ & $2880 \mathrm{rpm}$ \\
\hline
\end{tabular}

\subsection{Creation of fault}

The artificial faults in windings which are performed experimentally in laboratory, will use to study the differences in windings response that may be occur due to this fault. In this study, the artificial fault created between two phases of three-phase induction motor. Phase-to-phase (PP) fault occur when single-turn in phase $\mathrm{U}$ shorted with single-turn in phase $\mathrm{V}$ or between two coils from phases. This paper focus on phaseto-phase turns (PPT) faults, four units of TPIM were used to create short circuit fault between phases windings to get PPT fault. In this study, the short circuit fault was applied in the laboratory between phase U and phase $\mathrm{V}$ windings only. The PPT faults procedures for one case of TPIM are shown in Figure 2.

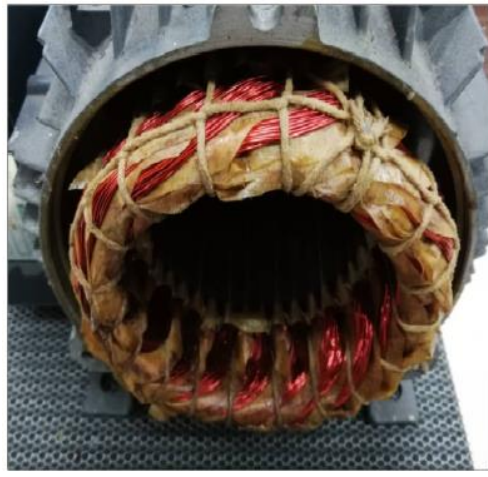

(a)

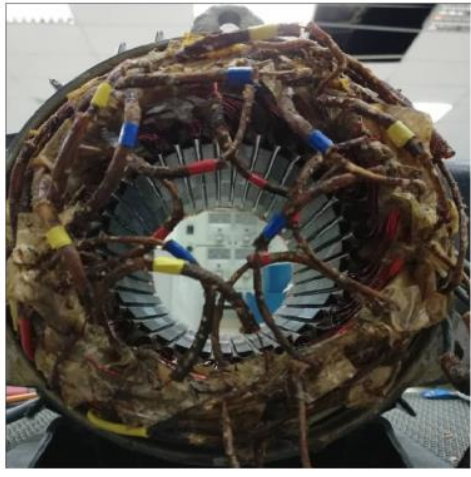

(b)

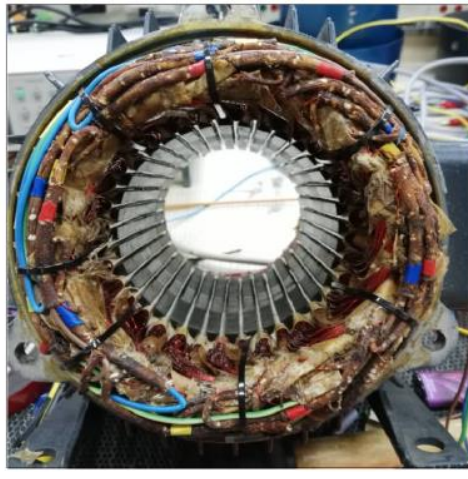

(c)

Figure 2. PPT faults creation stages on TPIM, (a) Normal winding, (b) Removing some conductors to create the fault, (c) Completed winding with PPT fault.

\subsection{FRA measurements setup}

Phase-to-phase turns (PPT) fault commonly occurs to TPIM. Generally, at any short-circuit (SC) in the windings suffer from insulation failure because of the thermal stress which occurs due to the increase of current in the windings. In this paper, FRA measurements are performed on phases $\mathrm{U}, \mathrm{V}$ and $\mathrm{W}$ to diagnose the fault in TPIM windings. The measurements are performed before and after the fault has created. Figure 3 shows connection between the equipments which are used to perform the FRA measurements. In this study, the windings have wye $(\mathrm{Y})$ connection configuration. With wye connection, the frequency responses can be measured between two phase terminals (U-V, V-W, and W-U) only, with assuming that the neutral point $(\mathrm{N})$ 
is hidden. The FRA measurements are made on four units of TPIM which are listed in Table 1. The winding frequency responses are later analyzed and interpreted.

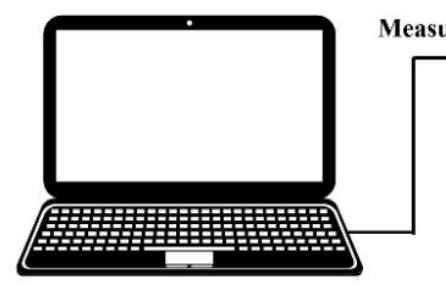

(a)

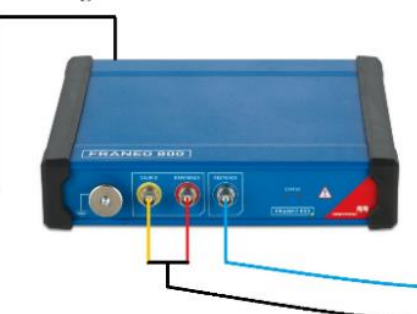

(b)

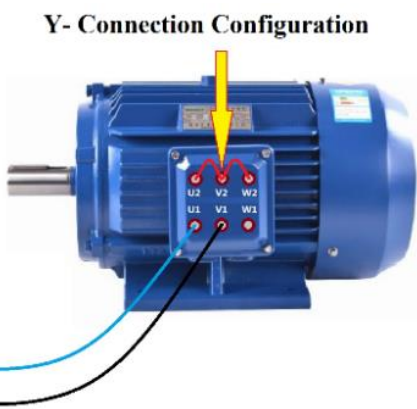

(c)

Figure 3. Equipments connection to measured FRA for motor windings (a) Computer, (b) FRANEO 800 equipment, (c) Three-phase induction motot

\section{FRA RESULTS AND ANALYSIS}

In this section, the FRA response results for the PPT fault created practically in the laboratory on TPIM stator windings are presented and discussed. For each case, three phases frequency response measured via two steps, the first one during healthy windings condition and the second at PPT fault in the TPIM windings. Figure 4, Figure 5 and Figure 6 shows the frequency responses (FR) curves of the tested four units. As shown, the FR curve was different from machine to other, this is likely depending on four TPIM units power rating.

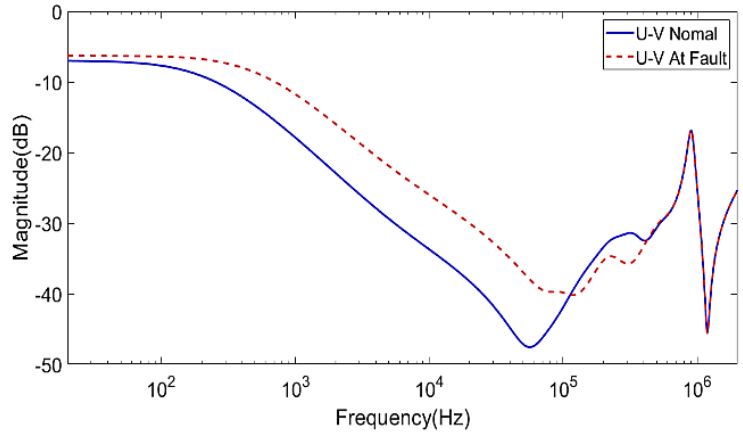

(a)

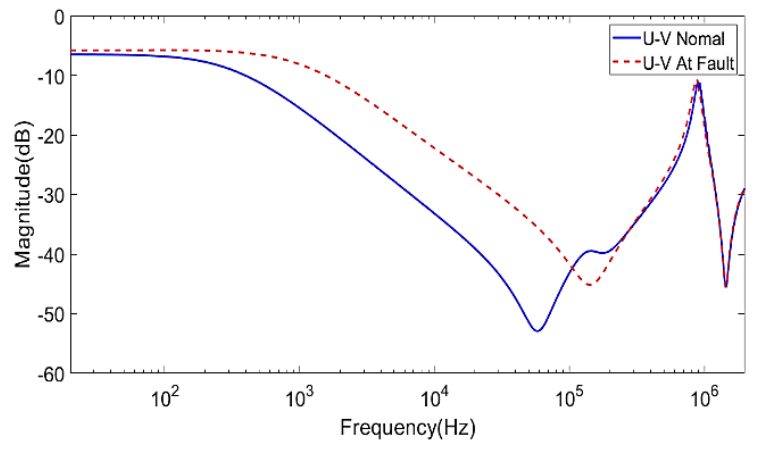

(c)

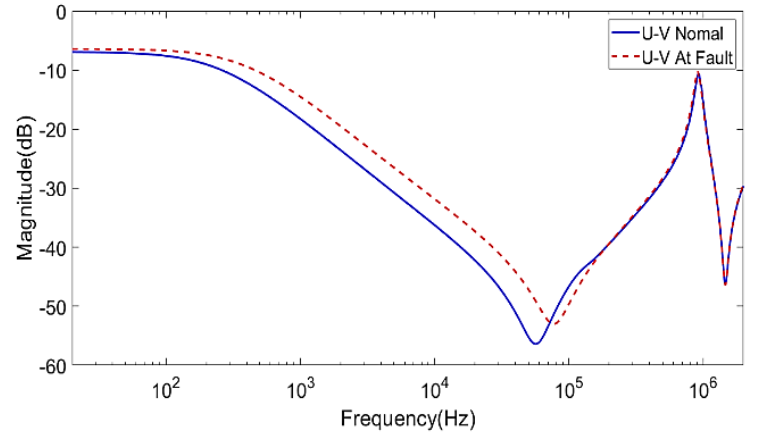

(b)

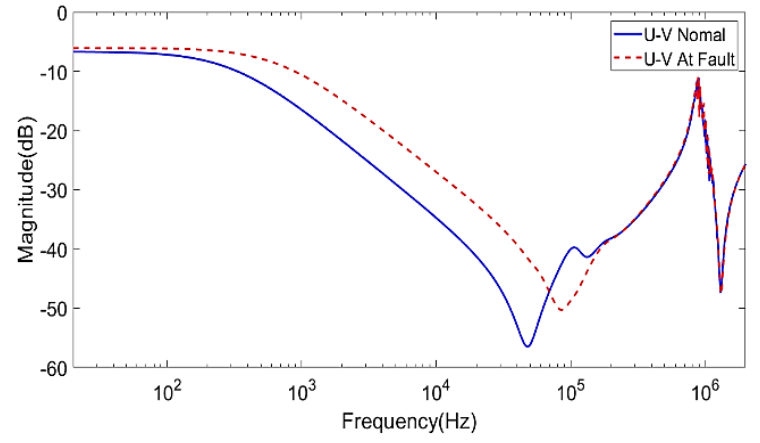

(d)

Figure 4. FRA Measurement for terminal U-V at normal condition and PPT fault in phases U and V. (a) FRA for 1HP TPIM, (b) FRA for 2HP TPIM, (c) FRA for 3HP TPIM and (d) FRA for 5.5HP TPIM. 


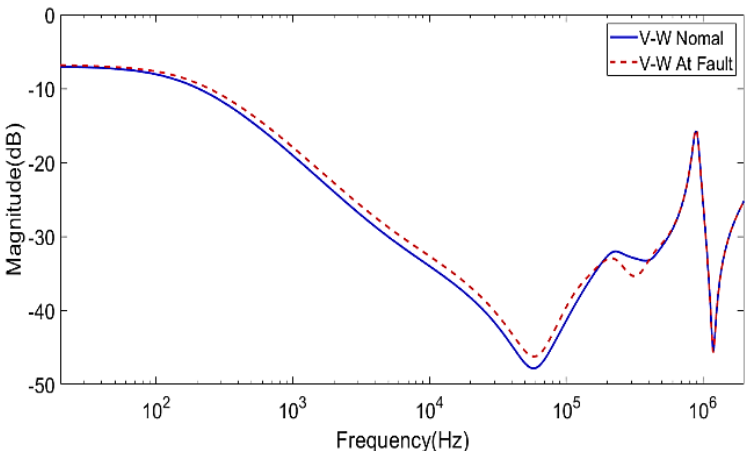

(a)

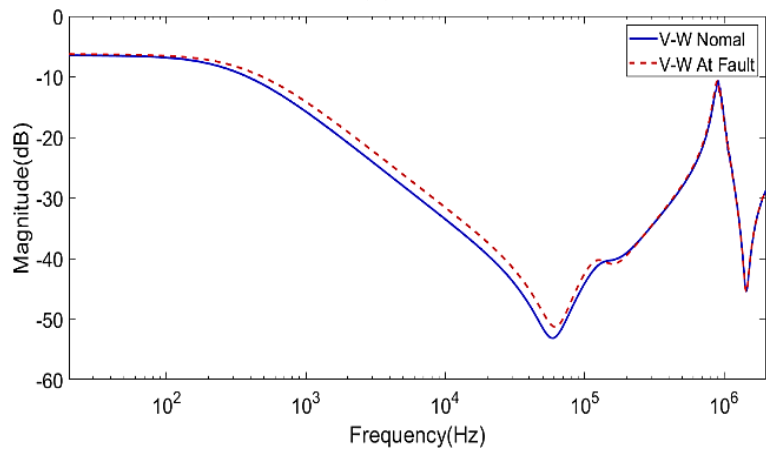

(c)

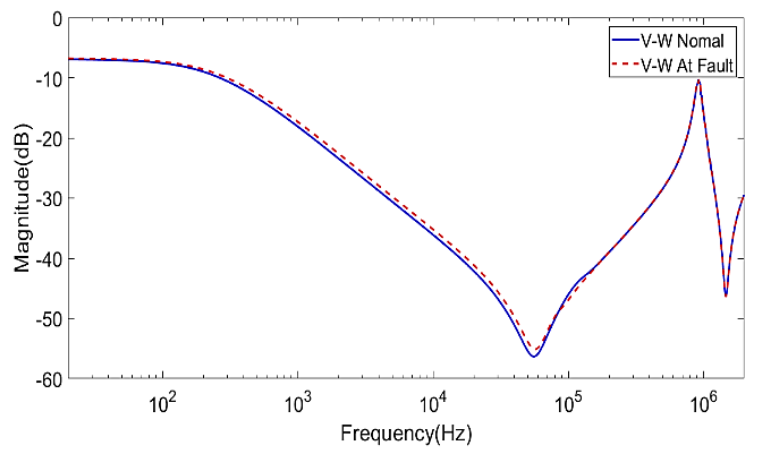

(b)

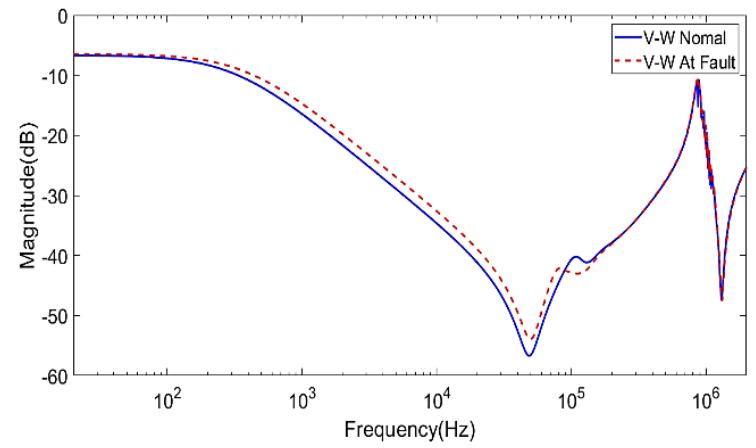

(d)

Figure 5. FRA Measurement for terminal V-W at normal condition and PPT fault in phases U and V. (a) FRA for 1HP TPIM, (b) FRA for 2HP TPIM, (c) FRA for 3HP TPIM and (d) FRA for 5.5HP TPIM.

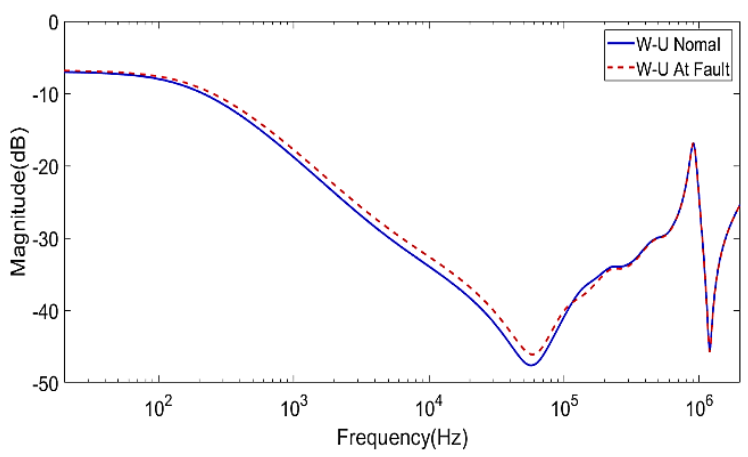

(a)

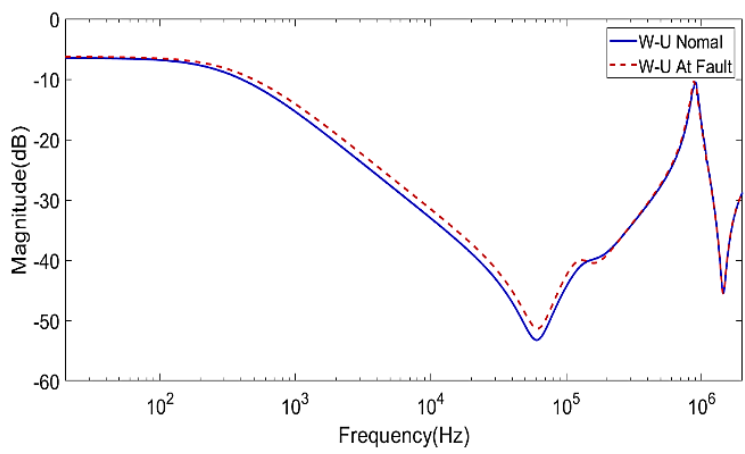

(c)

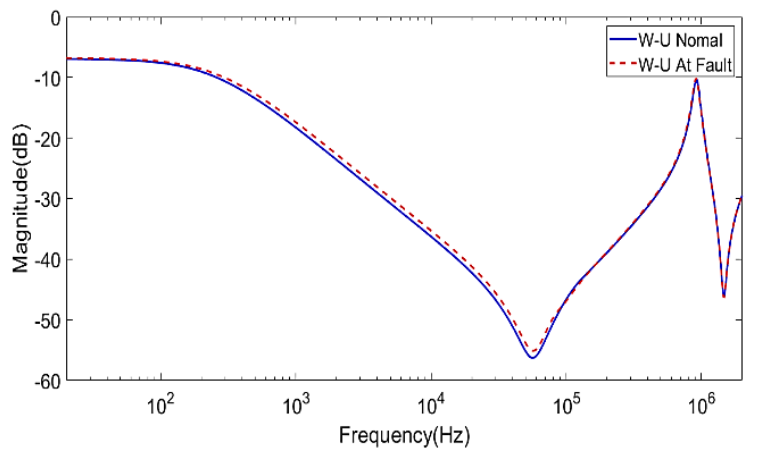

(b)

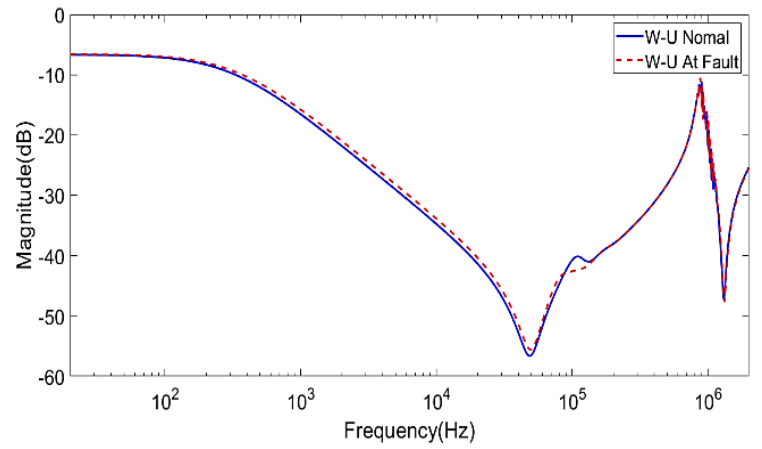

(d)

Figure 6. FRA Measurement for terminal W-U at normal condition and PPT fault in phases U and V. (a) FRA for 1HP TPIM, (b) FRA for 2HP TPIM, (c) FRA for 3HP TPIM and (d) FRA for 5.5HP TPIM. 
The main effect of PPT fault was by creats a short circuit between phases windings lead to reduce the number of turns less than the normal condition. Thus, that will reduce the windings length of the coils. So that, the total resistance of the coils that make up the phase will decrease. Also, the flux in the coils will reduce. Creation of the PPT fault will lead to reduced magnetizing inductance of phase $U$ and phase V, because of the shorted turns between phases $U-V$ and the turns removed from phase $U$ and phase $V$. Thus, causes an increase the magnitude of the response and this considered defective response. And surely, the comparison of frequency responses (FR) in case of normal condition and at PPT fault in windings was clearly visible in Figure 4, Figure 5 and Figure 6, and the responses shows the cases of effect according to the connections of measurements conducted, which are the FRA measured for terminals (U-V, V-W and W-U).

For more clarification, the magnitude of defective response between the reference FR and the FR at PPT fault condition for terminals U-V were very evidents as shown in Figure 4, because of the PPT fault was created in the phases $\mathrm{U}$ and $\mathrm{V}$ windings together since the beginning for all TPIMs. On the other hand, the healthy phase $\mathrm{W}$ from the other side.The reason for these defective response was due to the magnetizing inductance limitation in the phases windings of TPIM, which is directly affected when any fault occur in motor windings.

\section{ANALYSIS USING NCEPRI ALGORITHM}

NCEPRI algorithm was proposed in [30], [31] and has been used as one of statistical methods for analysing the FRA results. In this study, the NCEPRI algorithm is used for interpretation and validation the response. This performed by computing the effective deviation (ED) or assessment factor ( $\left.E_{12}\right)$ by using (1).

$$
E_{12}=\frac{1}{N} \sum_{i=1}^{N}\left(T F_{1 i}-T F_{2 i}\right)^{2}
$$

Where $N$ is the number of point in a frequency response, $T F_{1 i}$ and $T F_{2 i}$ are the transfer function values of the frequency response of normal winding and faulty winding respectively at frequency $i$.

NCEPRI algorithm was utilized for distinguish the differences between frequency responses at normal condition and with PPT fault case for four units which are clearly visible in Figure 4, Figure 5 and Figure 6. In this study, the frequency response (FR) curves divided into four regions according to the response wave-shape. As shown in Table 2.

Table 2. Assessment factor $\left(\mathrm{E}_{12}\right)$ of PPT fault frequency responses by using NCEPRI algorithm

\begin{tabular}{|c|c|c|c|c|c|c|c|c|c|c|c|c|}
\hline \multirow{2}{*}{$\begin{array}{l}\text { Frequency } \\
\text { range }\end{array}$} & \multicolumn{3}{|c|}{ E12 in $\mathrm{dB}$ for $1 \mathrm{HP}$ motor } & \multicolumn{3}{|c|}{ E12 in $\mathrm{dB}$ for $2 \mathrm{HP}$ motor } & \multicolumn{3}{|c|}{ E12 in $\mathrm{dB}$ for $3 \mathrm{HP}$ motor } & \multicolumn{3}{|c|}{ E12 in $\mathrm{dB}$ for $5.5 \mathrm{HP}$ motor } \\
\hline & U-V & V-W & W-U & U-V & V-W & W-U & U-V & V-W & W-U & $\mathrm{U}-\mathrm{V}$ & V-W & W-U \\
\hline $\begin{array}{l}20 \mathrm{~Hz}- \\
2 \mathrm{kHz}\end{array}$ & 4.3107 & 0.8479 & 0.7707 & 2.6807 & 0.5743 & 0.6341 & 4.9494 & 1.1235 & 0.8886 & 4.0093 & 1.2153 & 0.5342 \\
\hline $\begin{array}{l}2 \mathrm{kHz}- \\
20 \mathrm{kHz}\end{array}$ & 7.5660 & 1.3119 & 1.2834 & 4.3512 & 0.8767 & 0.9535 & 10.6256 & 1.9092 & 1.4839 & 7.5834 & 2.0130 & 0.8706 \\
\hline $\begin{array}{l}20 \mathrm{kHz}- \\
200 \mathrm{kHz}\end{array}$ & 7.0367 & 1.4621 & 1.3211 & 4.7302 & 0.9690 & 0.9171 & 11.4809 & 1.8078 & 1.5997 & 8.7552 & 2.2878 & 1.1205 \\
\hline $\begin{array}{l}200 \mathrm{kHz}- \\
2 \mathrm{MHz}\end{array}$ & 1.5733 & 0.8379 & 0.1595 & 0.4517 & 0.1341 & 0.2407 & 0.9908 & 0.2952 & 0.3493 & 1.1079 & 0.8431 & 1.1207 \\
\hline
\end{tabular}

The assessment factor (E12) values was calculated for all cases in this study by using the equation (1). Table 2 shows the values of E12 for the four units of TPIM. As clearly, the E12 values for PPT fault are high for the frequency region $(20 \mathrm{~Hz}-2 \mathrm{kHz})$, it ranged between (2.6807 to 4.9494) when it calculated for terminal U-V. And for terminals V-W and W-U the E12 ranged between (0.5342 to 1.2153). As E12 vales showed, the effective of fault was more evident at U-V calculation. This due to the impact of PPT fault was occured directly on this phase. Therefore, this region is considered as serious failure. For frequency regions $(2 \mathrm{kHz}-20 \mathrm{kHz})$ and $(20 \mathrm{kHz}-200 \mathrm{kHz})$, the E12 values for terminals $\mathrm{U}-\mathrm{V}, \mathrm{V}-\mathrm{W}$ and $\mathrm{W}-\mathrm{U}$ was ranged between (4.3512 to 11.4809$)$, (0.8767 to 2.2878 ) and (0.8706 to 1.5997$)$ respectively as shown in Table 2 . That mean it was higher than the first values. So that, this region is considered as serious distorted, this due to the effects of PPT fault in motor windings. For the frequency region $(200 \mathrm{kHz}-2 \mathrm{MHz})$, the recorded values were lower than the values in the rest regions. This means that the effect of PPT fault is relative in this frequency region. 


\section{CONCLUSION}

Phase to phase turns (PPT) fault in TPIM winding was presents in this paper. The comparison of frequency responses (FR) confirmed that the PPT fault in TPIM winding gives some of variation in the FRA response. The variations in FRA signatures for windings was interpreted and analyzed in section 4 . A finding of this paper, it has been proven that the defect that occurred due to PPT fault can be diagnose and detected, through the variation in the FRA response in phases when measuring the frequency response. And also, this paper presented the validation for FRA at the PPT fault case by using one of a certified statistical indicators, which is NCEPRI algorithm. Where, the calculation of the assessment factor (E12) shows the highest distortion indicator of frequency regions that has low and medium frequencies range. And in high frequencies range, the distortion level will be relatively insignificant. The method proposed in this paper had a useful result, it can be considered as a new method to detection and diagnosis the PPT fault in three-phase induction motor. And also, the applications of developed method can be used for diagnosis and detection the other types of faults in TPIM.

\section{REFERENCES}

[1] Zamudio-Ramirez, Israel, Roque Alfredo Osornio-Rios, Miguel Trejo-Hernandez, Rene de Jesus RomeroTroncoso, and Jose Alfonso Antonino-Daviu, "Smart-sensors to estimate insulation health in induction motors via analysis of stray flux," Energies, vol. 12, no. 9, pp. 1658, 2019.

[2] Akar Mehmet, Ankaya Ilyas C., "Broken rotor bar fault detection in inverter-fed squirrel cage induction motors using stator current analysis and fuzzy logic," Turk J Elec Eng \& Comp Sci, vol. 20, no. 1, pp. 1077-1089, 2012.

[3] Pezzani C, Donolo P., Bossio G., Donolo M., Guzman A., Zocholl S. E., "Detecting broken rotor bars with zerosetting protection," Industrial \& Commercial Power Systems Technical Conference (I\&CPS), IEEE/IAS 48th., pp. 1-12, 2012.

[4] Qi, Xiang., "Practical Circuit design to protect motor's phase failure operation," 2010 Asia-Pacific Conference on Power Electronics and Design, pp. 104-107, 2010.

[5] G. B. Kliman, W. J. Premerlani, R. A. Koegl, and D. Hoeweler, "A new approach to on-line turn fault detection in ac motors," Proc. IEEE Industry Applications Soc. Annual Meeting Conf., San Diego, CA, pp. 687-693, 1996.

[6] P. J. Tavner and J. Penman, "Electrical techniques for monitoring," in Condition Monitoring of Electrical Machines, Letchworth, Hertfordshire, U.K.: Research Studies Press Ltd., vol. 1, pp. 93-132, 1987.

[7] P. Zhang, Yi Du, T. G. Habetler, Bin Lu, "A survey of condition monitoring and protection methods for mediumvoltage induction motors," IEEE Trans. Ind. Appl, vol. 47, no. 1, pp. 34-46, 2011.

[8] Benbouzid, M. El Hachemi, "A review of induction motors signature analysis as a medium for faults detection," IEEE transactions on industrial electronics, vol. 47, no. 5, pp. 984-993, 2000.

[9] Siddique, Arfat, G. S. Yadava, and Bhim Singh, "A review of stator fault monitoring techniques of induction motors," IEEE transactions on energy conversion, vol. 20, no. 1, pp. 106-114, 2005.

[10] Singh, Arvind, Bevon Grant, Ronald DeFour, Chandrabhan Sharma, and Sanjay Bahadoorsingh, "A review of induction motor fault modeling," Electric Power Systems Research, vol. 133, pp. 191-197, 2016.

[11] M. Arkan, D. K. Perovic, and P. Unsworth, "Online stator fault diagnosis in induction motors," Proc. Inst. Elect. Eng., Elect. Power Appl., vol. 148, no. 6, pp. 537-547, 2001.

[12] A. H. Bonnet and G. C. Soukup, "Cause and analysis of stator and rotor failures in three-phase squirrel-cage induction motors," IEEE Transactions on Industry Application, vol. 28, no. 4, pp. 921-937, 1992.

[13] J. Scottile, J. L. Kohler, "An on-line method to detect incipient failure of turn insulation in random-wound motors," IEEE Trans. on Energy Conversion, vol. 8, no. 4, pp. 762-768, 1993.

[14] P. J. Tavner and J. Penman, "Temperature monitoring," in Condition Monitoring of Electrical Machines, Letchworth, Hertfordshire, U.K.: Research Studies Press Ltd., vol. 1, pp. 228-239, 1987.

[15] S. B. Lee, R. M. Tallam and T. G. Habetler, "A robust, on-line turn-fault detection technique for induction machines based on monitoring the sequence component impedance matrix," IEEE Trans. Power Electronics, vol. 18, no. 3, pp. 865-872, 2003.

[16] C. Xianrong, V. Cocquempot, and C. Christophe, "A model of asynchronous machines for stator fault detection and isolation," IEEE Trans. Ind. Electron., vol. 50, no. 3, pp. 578-584, 2003.

[17] F. Zidani, M. E. H. Benbouzid, D. Diallo, and M. S. Nait-Said, "Induction motor stator faults diagnosis by a current Concordia pattern-based fuzzy decision system," IEEE Trans. Energy Convers., vol. 18, no. 4, pp. 469-475, 2003.

[18] D. C. Patel, M. C. Chandorkar, "Modeling and analysis of stator interturn fault location effects on induction machines," IEEE Trans. Ind. Electronics, vol. 61, pp. 4552-4564, 2014.

[19] M. E. H. Benbouzid, M. Vieira, C. Theys, "Induction motors' faults detection and localization using stator current advanced signal processing techniques," IEEE Trans. Power Electron., vol. 14, no. 1, pp. 14-22, 1999.

[20] Tushar G. Vilhekar, Makarand S. Ballal, and H. M. Suryawanshi, "Application of double parks vector approach for detection of interturn fault in induction motor," International Conference on Condition Assessment Techniques in Electrical Systems (CATCON), pp. 173-178, 2015.

[21] Gandhi, Ketan R., and Ketan P. Badgujar, "Artificial neural network based identification of deviation in frequency response of power transformer windings," 2014 Annual International Conference on Emerging Research Areas: Magnetics, Machines and Drives (AICERA/iCMMD), pp. 1-8. IEEE, 2014. 
[22] F.R. Blnquez, C.A. Platero, E. Rebollo, F. Blzquez, "Field-winding fault detection in synchronous machines with static excitation through frequency response analysis," International Journal of Electrical Power \& Energy Systems, vol. 73, pp 229-239, 2015.

[23] J. C. G. Arispe and E. E. Mombello, "Detection of failures within transformers by FRA using multiresolution decomposition," IEEE Trans. Power Deliv., vol. 29, no. 3, pp. 1127-1137, 2014

[24] Vilhekar, Tushar Gulabrao, Makarand Sudhakar Ballal, and Bhimrao S. Umre, "Application of Sweep Frequency Response Analysis for the detection of winding faults in induction motor," IECON 2016-42nd Annual Conference of the IEEE Industrial Electronics Society, pp. 1458-1463, 2016.

[25] "IEEE guide for the application and interpretation of frequency response analysis for oil-immersed transformers," IEEE power and energy society, IEEE Std C57.149-2012, pp. 1-72, 2013.

[26] P. Picher, "Mechanical condition assessment of transformer windings using frequency response analysis (FRA)," Cigre, Evaluation, vol. A2.26, pp. 30-34, 2008.

[27] Behjat V., Vahedi A., Setayeshmehr A., Borsi H., Gockenbach E., "Sweep frequency response analysis for diagnosis of low level short circuit faults on the windings of power transformers: An experimental study," International Journal of Electrical Power and Energy Systems, vol. 42, no. 1, pp. 78-90, 2012.

[28] S. Al-Ameri, A. A. Alawady, M. F. M. Yousof, H. Ahmad, Ali. A. Salem, and M. A. Talib, "Frequency response analysis for transformer tap changer damage detection," International Journal of Power Electronics and Drive Systems (IJPEDS), vol. 11, no. 1, pp. 350-358, 2020.

[29] N. F. M. Yasid, A. A. Alawady, M. F. M. Yousof, S. Al-Ameri and M. S. Kamarudin, "Interpretation of sweep frequency response analysis traces on inter-turn short circuit fault," International Journal of Power Electronics and Drive Systems (IJPEDS), vol. 11, no. 1, pp. 309-316, 2020.

[30] OMICRON, "FR analyzer user manual - SFRA analyzer for power transformer winding diagnosis," OMICRON electronics, 2006.

[31] NCEPRI, "Application guideline for transformer winding distortion test technology," 1999.

\section{BIOGRAPHIES OF AUTHORS}

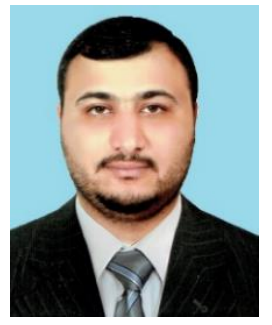

Ahmed Allawy Alawady. He received his bachelor degree (B.Eng.) in Electrical Engineering from University of Kufa, Iraq in 2007. He received master degree (M.Eng.) in Electrical power system from (SHUATS), India in 2012. He is a lecturer at Collage of Technical Engineering, The Islamic University, Iraq since 2007. Currently he is pursuing his Ph.D. Degree in Universiti Tun Hussein Onn Malaysia (UTHM). His research is on motors faults detection using Frequency Response Analysis (FRA) technique.

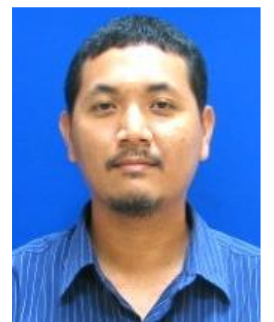

Mohd Fairouz Mohd Yousof. He obtained Dip. Eng, B. Eng and M. Eng from Universiti Teknologi Malaysia. He completed his Ph.D. study in 2015 from The University of Queensland, Australia and currently a lecturer at the Department of Electrical Power Engineering, Universiti Tun Hussein Onn Malaysia (UTHM). He was a visiting researcher for a year with TNB Research in 2018. His main research is condition-based monitoring and assessment of power transformer and rotating machine. He is actively involved with projects from local and international industries.

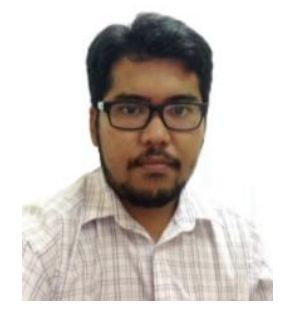

Norhafiz Azis. He received B. Eng degree in Electrical and Electronic Engineering (2007) from Universiti Putra Malaysia and PhD degree in Electrical Power Engineering (2012) from The University of Manchester in UK. Currently, he is an associate professor at the Department of Electrical and Electronic Engineering, Universiti Putra Malaysia, Malaysia. His research interests are in-service ageing of transformer insulation, condition monitoring, asset management, high voltage engineering and alternative insulation materials for high voltage equipment.

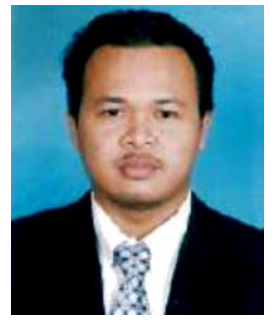

Mohd Aizam Talib. He received his Bachelor in Electrical Engineering from the University of Portsmouth, UK in 1997, Master degree in Electrical Engineering from Universiti Tenaga Nasional (UNITEN), Malaysia in 2001, and Ph.D. degree from Universiti Teknologi Malaysia in 2017. Upon graduation in 1997, he worked with ABB Transmission and Distribution Sdn Bhd as a Design Engineer. Since 1998, he has been employed by TNB Research Sdn Bhd as a Research Engineer and now is a technical expert on transformer. His research interests are in transformer condition monitoring, insulation diagnostic and dielectric measurements. 